Department of Business Administration

UZH Business Working Paper Series

(ISSN 2296-0422)

\author{
Working Paper No. 335 \\ Lessons in Fluidity: Anonymous and the Communicative \\ Formation of Organizational Identity
}

Leonhard Dobusch

Dennis Schoeneborn

20 June 2013

Work in progress: Please do not cite without the authors' permission

University of Zurich, Plattenstrasse 14, CH-8053 Zurich, http://www.business.uzh.ch/forschung/wps.html 
UZH Business Working Paper Series

\section{Contact Details}

\section{Leonhard Dobusch}

Freie Universität Berlin, Germany

leonhard.dobusch@fu-berlin.de

\section{Dennis Schoeneborn}

University of Zurich, Switzerland

dennis.schoeneborn@uzh.ch

This paper has been presented at the International Communication Association’s Annual Conference (ICA 2013) in London, UK, June 17-21, 2013. 


\title{
LESSONS IN FLUIDITY: ANONYMOUS AND THE COMMUNICATIVE FORMATION OF ORGANIZATIONAL IDENTITY
}

\begin{abstract}
Most research on organizational identity tends to take an essentialist perspective, differentiating between an identity construed internally by members of the organization and an image construed by external actors. However, the duality of identity and image struggles with capturing more fluid, open, or partial organizational arrangements, where it is difficult to uphold this distinction. Looking at the case of the hacker collective Anonymous as an extreme example of organization, this paper proposes to adopt a communication-centered perspective in order to better understand the formation of organizational identity. Drawing on the emerging "communicative constitution of organizations" (CCO) framework, we transcend both an essentialist and a member-centered view by arguing that organizational identity is achieved through communicative events that demarcate the boundaries between actions attributed either to the organization or to the organizational environment.
\end{abstract}

\section{KEYWORDS}

Anonymous; "communication as constitutive of organizations" (CCO); organizational communication; organizational identity; organization theory; partial organizations 


\section{LESSONS IN FLUIDITY: ANONYMOUS AND THE COMMUNICATIVE FORMATION OF ORGANIZATIONAL IDENTITY}

“We are Anonymous. We are Legion. We do not forgive. We do not forget. Expect us." Anonymous

Across theoretical approaches, the question of organizational identity has become one of the most discussed issues in the realm of research on organizations (e.g. Gioia et al., 2013; Schultz \& Hernes 2013). In the introduction to a special topic forum on organizational identity, Albert and his colleagues (2000, p. 13) argued that "in the absence of an externalized bureaucratic structure, it becomes more important to have [...] a clear sense of the organization's identity", leading the organization to "reside in the heads and hearts of its members.” Studies of identity formation (e.g., Gioia et al., 2010; Fiol \& Romanelli, 2012; Kroezen \& Heugens, 2012) conceptualize organizational identity as something that is construed by the members of an organization. The centrality of members is further underlined by the conceptual demarcation between identity that is primarily construed internally by the organization's members and image that is primarily construed by external constituents of an organization; a distinction that is problematized but nevertheless upheld in the recent review on organizational identity by Gioia and his colleagues (2013).

However, these traditional conceptions of organizational identity fall short in explaining the emergence and role of identity in more fluid and precarious organizational forms such as network-type (Huemer et al., 2004), virtual (Wiesenfeld et al., 1998), or clandestine and covert (Scott, 2013; Stohl \& Stohl, 2011) organizations. Empirical examples of these organizations include, for instance, the terrorist network of al Qaeda (Stohl \& Stohl, 2011; Schoeneborn \& Scherer, 2012) or online communities such as the hacker collective “Anonymous” (Coleman, 2012a, 2012b). In such of “partial organizations” (Ahrne \& 
Brunsson, 2011), i.e. organizations that lack some features commonly associated with formal organizations (e.g., formal membership rules), the growing importance of a shared identity for coordinating activities is at odds with unclear and unstable attribution of membership. Moreover, unclear and unstable membership blurs the distinction between identity and image. Consequently, in this paper, we deal with the research question how organizational identity is formed in contexts of unclear membership and fluid organizational boundaries?

To address this question, we propose to turn from a membership-centered to a communication-centered view on organizational identity that is grounded in a theoretical endeavour known as “communication as constitutive of organizations” (CCO) (for recent overviews, see Ashcraft et al., 2009; Brummans et al., forthcoming; Cooren et al.; 2011). We argue that this view enables us to show how organizational identity is accomplished and maintained through communicative events that demarcate the boundary between actions attributed to the organization and actions attributed to the organizational environment. Furthermore, this theoretical lens helps conceptualize why and how non-members can contribute to organizational identity formation in much the same way as members do (Kjaergaard et al, 2011; Fiol and Romanelli 2012), since in a communication-centered perspective both members and non-members belong to the - albeit structurally coupled environment of the organization as a communicative entity (Seidl \& Becker, 2006). In this regard, a communication-centered lens (Cooren et al., 2011) helps to account for the most loose and fluid forms of organizations and the ways in which they accomplish an identity, even in cases where organizational membership is unstable or unclear.

On the empirical level, we address our research question (as outlined above) with a dual strategy: First we historically reconstruct the genesis of the organizational identity of the online hacker collective 'Anonymous'. We are thereby contributing to the still scarce body of 
studies on organizational identity formation. Second, we look at critical communicative episodes challenging this organizational identity and the practices of communicative boundary maintenance targeted at resolving them. For both these strategies we rely on publicly accessible data such as media coverage as well as online archival data.

On the conceptual level, our study of Anonymous is based on a CCO perspective provides three main contributions to the literature on organizational identity in particular as well as organization studies more generally. First, our communication-centered analysis lens represents a process approach as recently called for by Gioia et al. (2013), thereby transcending essentialist views on organizational identity. Focusing on episodes of communicative events, this process perspective accounts for the role of follow-up communication in identity reproduction and change in the course of identity crisis. Second we complement the current member-focused view on organizational identity formation (e.g., Gioia et al., 2010; Kroezen \& Heugens, 2012), which allows us to resolve the duality of identity and image many previous works on identity are struggling with By de-centering members in identity formation processes, a CCO framework provides a conceptual umbrella for integrating the extensive lists of external factors found to influence identity formation processes such as peer organizations (Gioia et al., 2010), national identity (Jack \& Lorbiecki, 2007), cultural framing (Glynn \& Watkiss, 2012), or the media (Kjaergaard et al., 2011; see also Gioia et al., 2013, p. 163ff.). Third, we empirically demonstrate that the processual nature of a CCO perspective is particularly apt to capture identity formation in settings that lack typical elements of traditional organizations, e.g., the capability to decide on the inclusion or exclusion of organizational members (also known as "partial organizations"; Ahrne \& Brunsson, 2011) As illustrated by our study of Anonymous, in the lack of an overview of its own members, the organization's identity formation needs to take place largely through publicly visible communication events. Hence, these special cases of 
organizations naturally bring the communicative nature of identity formation to the fore and allow us to study the basic communicative mechanisms that stabilize the organization's boundary even in the wake of fluidity (Schreyögg \& Sydow, 2010).

\section{THEORETICAL CONSIDERATIONS ON ORGANIZATIONAL IDENTITY FORMATION AND BOUNDARY MAINTENANCE}

\section{Essentialist views on identity and identity formation}

In their seminal article on organizational identity, Albert and Whetten (1985) define identity as convergence in members' beliefs on central, distinctive, and enduring features of an organization (see also Ravasi \& van Rekom, 2003). Specifically, the issue of endurance sparked a lot of scholarly debate and research. Reflecting on the three decades of organizational identity research after Albert and Whetten's major contribution, Gioia et al. (2013 p. 131) broadly distinguish between enduring and dynamic notions of identity in the pertinent literature. The former body of literature emphasizes the stability and permanence of identity, which may result from internal dynamics (Ashforth \& Mael, 1989; Brown \& Starkey, 2000) or institutional pressures (Benner, 2007; Porac et al., 1999). The latter, more dynamic view conceptualizes identity instead as fluid and inherently unstable (Gioia et al., 2000; Schultz \& Hernes, 2013), which ultimately also allows for intended or unintended change of identity (e.g. Ashforth et al., 2011; Gioia \& Thomas, 1996; Seidl, 2005).

However, as Gioia et al. (2013, p. 180) assert, both streams of the identity literature ultimately share an “essentialist” perspective on the phenomenon: 
We would note that the discourse on the dynamic aspects of identity, especially the 'enduring' vs. 'change' debate, suggests the predominance of an essentialist view of organizational identity as 'thing'. Whether one holds a social actor view or a social construction view, the overriding image of identity is that of some ‘entity' that experiences change.

The inherent limitations of such an essentialist conception of identity might also be one of the reasons for the surprisingly few studies on the processual nature of identity formation so far (apart from recent exceptions such as Schultz and Hernes, 2013). Gioia et al. (2013), for instance, only mention two empirical studies (Gioia et al., 2010; Kroezen \& Heugens 2012) and one conceptual exception (Ashforth et al., 2011) in this regard.

In line with process views (e.g., Hernes, 2008; Langley, 1999; Van de Ven \& Poole, 1995) and practice perspectives (e.g., Schatzki et al., 2001) that focus on “organizing” rather than “organizations”, we propose to conceptualize identity as being continuously reproduced rather than being a more or less stable entity. Such a process notion of identity is also favored by Schultz and Hernes (2013, p. 1), who view “identity construction as an ongoing process” with the basic assumption that "not only is the future open but also that the past is open to (re)interpretation.” Nevertheless, in their analysis of the LEGO case, Schultz and Hernes (2013) exclusively focus on how organizational members engage in identity re-construction. And Fiol and Romanelli (2012, p. 605) also privilege members' role in identity formation, while acknowledging that these may "face negotiated constraints on identity characteristics imposed by outsiders”. By drawing on communication events as main units of our analysis, we intend to critically question the privileged role commonly attributed to members in processes of identity formation and reproduction. 


\section{Identity formation and external actors: the duality of identity and image}

The dominance of member-centered views on organizational identity is already present in Albert and Whetten (1985), whose definition of identity explicitly and exclusively refers to organizational members’ perceptions. Such a member-centered view of identity and identity formation has largely prevailed ever since. While Czarniawska (1997, p. 49f.), for instance, treats "identity as a narrative, or, more properly speaking, as a continuous process of narration“, she nevertheless points to members such as PR officers or CEOs as the potential narrators of organizational identity as a form of "organizational autobiography”. At the same time, however, she acknowledges that not only the (organizational) "narrator" but also his or her (external) “audience are involved in formulating, editing, applauding and refusing various elements of the ever-produced narrative” (ibid.).

Similarly, recent empirical studies on identity (Gioia et al., 2010; Kjaergaard et al., 2011; Schultz \& Hernes, 2013) have increasingly stressed the importance of external actors in processes of organizational identity construction. For instance, Schultz and Hernes’s (2013) investigation of the LEGO case supports earlier research by Dutton and Duckerich (1991) that discrepancies between identity and externally construed images might trigger intense selfscrutiny and thus may serve as an important resource for change (see also Christensen et al., 2013). In addition to this, studies on corporate branding assume a strong coherence between the organization's identity, image, and culture (Hatch \& Schultz, 2000; Christensen \& Cornelissen, 2011). What is more, Kjaergaard et al. (2011: 525) argue that "news media act as a 'mirror', to which members respond by constantly comparing their own beliefs with the images they see refracted in it.” Finally, Gioia et al. (2010) conclude that “[o]rganizational identity is progressively, even continuously, negotiated by organization members - via their interactions with each other and with external stakeholders.“ 
But when trying to theoretically account for the role of external actors in identity formation and re-production, there is a tendency to run into the conceptual wall between the constructs of organizational identity and image. Gioia et al. (2013, p. 135f., emphasis in original) acknowledge this tension when they recognize that empirical studies on identity tend to be "at odds with the widely held understanding among organizational identity scholars that identity is internally defined”. Instead, the authors (Gioia et al., 2013, p. 160) argue that “organizational identity formation processes involve the co-evolution of understandings, claims, and institutional forces that are not only complementary (Ravasi \& Schultz, 2006), but mutually constitutive (Gioia et al., 2010).” However, by stating such a ‘co-evolution’ of identity and image, which form an "inextricably intertwined relationship" (Gioia et al. 2000; cited in Gioia et al. 2013: 175), the theoretical relationship of this duality between identity and image nevertheless remains opaque. Consequently, it ultimately remains a black box how this co-evolution works.

In sum, we believe that opening the black box of co-evolution between identity and image requires a processual perspective that is able to account for co-construction of identity by members as well as non-members of an organization. As we will argue in the next section, the key we are suggesting for opening this black box is a communicatio-centered instead of a member-centered perspective on identity formation.

\section{A communication-centered perspective on organizational identity}

In their review of the organizational identity literature, Gioia et al. (2013, p. 160) highlight that organizational identity formation involves the co-evolution of (internal) identity and (external) image. Because of this co-evolution, the authors conclude that especially the processual nature of identity formation deserves further exploration. This theoretical turn from an essentialist towards a processual view on identity exhibits a natural fit, as we believe, 
to a recently emerging stream of research within organization theory that puts communication at the center of attention (e.g., Putnam \& Nicotera, 2009). More specifically, these works ascribe to practices of communication and language use a constitutive role in the formation of organizations (e.g., Ashcraft, Cooren \& Kuhn, 2009; Cooren et al., 2011). The underlying idea of these works is that organizations do not primarily consist of their "members" but rather they come into being through the "imbrication” (i.e. a recursive process of adding new layers; Taylor \& Van Every, 2000) of conversations and texts which collectively evoke and stabilize the organization as an identifiable entity or actor (Cooren, 2012). As Christensen and Cornelissen (2011, p. 405f.) put it: "Depending on the connections that individuals make while communicating, the organization and its identity is constructed rather than antecedently given or residing in individuals“. The "communication as constitutive of organizations” or, in short, “CCO” perspective (Brummans et al., 2013) is informed by various schools of thought, particularly the works of Latour (Cooren, 2012; Robichaud et al., 2004), Giddens (McPhee \& Zaug, 2009), and Luhmann (Seidl \& Becker, 2005), that all share the idea of a communicative construction of social reality (Cooren, 2012). The Luhmannian variant of CCO thinking goes even further than this by suggesting that a specific kind of communication events, i.e. the communication of decisions which, in turn, serves as a premise for follow-up decisions to occur, represents the constitutive and self-perpetuating force of organizations (e.g., Luhmann, 2000; Nassehi, 2005). We argue that the switch to communication events as the main building blocks of organizations (Ashcraft et al., 2009; Blaschke et al., 2012) is particularly advantageous in the context of our inquiry, as it allows to capture the emergence and perpetuation of organizations and their identity even when membership or boundaries are unstable or unclear such as in the case of Anonymous.

From the CCO literature, we can derive three central assumptions on the formation of organizational identity that will prove helpful for the further course of our analysis: 
(1) Continuous need for boundary maintenance through membership negotiation: The

CCO perspective suggests turning to communication as the primary mode of explanation for studying organizational phenomena (e.g., Cooren, 2012; Craig, 1999; Deetz, 1994). This theoretical shift, in turn, implies to look at the formative character of language use for organizations (e.g., Cooren et al., 2011) rather than the (heroic) agency of individual human actors in organizational settings (e.g., managers; cf. Fairhurst, 2007). By grasping organizations as being grounded in something as ephemeral and elusive as communication, the proponents of the CCO perspective emphasize the precarious character of organizations (Cooren et al., 2011)., as they face the continuous need to (re-)stabilize the organizational boundary in and through communication. In other words, the organizational boundary is seen here not as the firm building's brick walls or as factory site's wired fence, but as a symbolic boundary that needs to be continuously maintained in communicative practices (Schoeneborn, 2011). This is also why "membership negotiation” (McPhee \& Zaug, 2009) is seen here as one of the key communicative practices that constitute and ultimately stabilize organizations as processual entities. Through "membership negotiation”, organizations include or exclude individual human actors from participation in the very communicative processes that constitute the organization.

In the same context, and especially in works that follow the Luhmannian variant of CCO thinking (Luhmann, 2000; Mohe \& Seidl, 2011; Seidl \& Becker, 2006), scholars suggest that individual human actors need to be seen as part of the organization's environment. In other words, since the organization is conceptualized as consisting primarily of communication processes (see also Taylor \& Van Every, 2000), individual human actors only become instantiated as members through the communicative actions they mobilize "on behalf of" the organization (cf. Cooren 2012 Luhmann 2000). However, in this context, it is important to note that proponents of the CCO perspective put forth a rather wide notion of communication 
which includes not only verbal but also non-verbal forms of communicative action inherent mimics, gestures or other bodily acts (cf. Cornelissen, Clarke and Cienki 2012; Luhmann 1992). These non-verbal forms of communication can similarly contribute to the processual constitution of organization, as long as they involve the attribution of meaning related to the respective organization (Ashcraft et al., 2009).

(2) Identity formation through public (auto-)communication: Communicative practices of membership negotiation (McPhee \& Zaug, 2009) not only draw a (more or less) clear-cut boundary between organization and its environment (e.g., by excluding individual actors from participation in the organizational endeavor) but also allow organizations to reaffirm their own organizational identity in a self-referential way (cf. Seidl, 2005). Similarly, Morsing (2006) highlights that organizations tend to engage in practices of "strategic autocommunication” in the public arena, that is, an organization's efforts to strengthen and shape its (internal) identity also through external communication activities (see also Kjaergaard et al., 2011). Morsing argues that this form of communication is especially likely to occur in situations where the range of members is unknown to the organization itself (as in the case of Anonymous) or where membership is rather informal. What is more, external perceptions of an organization re-enter the organization, for instance, by new members that were attracted by an organization's “recruitment image” (Gatewood et al., 1993). This emphasis on the importance of identity formation mirrored in the light of external audiences resonates well with the recent call by Gioia et al. (2013) for further inquiries into the performative nature of organizational identity. Similarly to the works by Morsing (2006) or Kjaergaard et al. (2011), Gioia and his colleagues (2013, p. 167) draw on concepts like the 'self-other' (Ybema et al., 2009) and highlight the "importance of negotiating identity claims not just among insiders but also between insiders and outsiders [...].” In other words, organizations tend to form and maintain their identity fundamentally also in direct interactions with their environment. Again, 
and as argued above, these arguments render questionable a clear-cut separation of identity and image (Gioia et al., 2013).

(3) Organizational identity formation in the lack of membership: If organizational identity formation can, to a large extent, take place in the public arena, decisions on who is allowed to speak "on behalf of” the organization and who is not gain crucial importance (cf. Cooren, 2012). This problem is especially prevalent in social-movement-type organizations which can lack an overview of their own members as well as the capability to decide on who is an organizational member and who is not (e.g., Anonymous or al Qaeda; cf. Scott 2013). Again, we argue that it is useful in this context to draw on the Luhmannian tradition of CCO thinking, where organizations are primarily seen as “decided orders” that are accomplished in processes of communication (see Ahrne \& Brunsson, 2011; Luhmann, 2000). According to this view, organizations perpetuate their existence by interconnecting one event of decisionfocused communication to the next. In this processual understanding of organizations, past decisions serve as decision premises for follow-up decisions thus creating a self-perpetuating process (Nassehi, 2005). One such decision premise may be the attribution of organizational membership to an individual human actor. However, in organizational exemplars where clear membership is missing and the organization is "partial" in character (Ahrne and Brunsson, 2011), the role of organizational membership as one of the most central decision premises of organizations needs to be substituted by other functional equivalents of membership as a decision premise. In other words, if membership is unclear or unstable and thus cannot serve well as a decision premise for future decisions, it is replaced by more reliable forms of decision premises, e.g., past decisions on which communication channels to use (cf. Luhmann, 2000). 
Taken together, the CCO view enables us to overcome two main gaps in the literature on organization identity formation: First, the CCO perspective allows for going beyond both essentialist and process views of identity formation (cf. Gioia et al. 2013) by specifying a 'third way' that places communication at the center of attention. This focus on communication, in turn, allows transcending previous works which are ultimately still bound to the idea of individual human membership and privilege the role of members over nonmembers (e.g., Schultz \& Hernes, 2013). Therefore, we believe a communication-centered lens has a particular strong fit to partial organizations such as Anonymous. Second, the CCO view helps to transcend the classical distinction between identity and image (Gioia et al. 2013), by bringing the notion of image back in' and by emphasizing the importance of “strategic auto-communication” (Morsing, 2006) in the light of the "self-other” (Ybema et al., 2009). In other words, these works highlight that communication practices in the public or external domain are of similar importance to identity formation as the internal domain (especially in organizations as fluid as Anonymous and where memberships are even hidden to the organization itself; cf. Scott 2013).

\section{CASE SELECTION AND DESCRIPTION}

\section{What is Anonymous and why it is relevant}

To showcase the added value of a communication-centered perspective on organizational identity formation and re-production, we turn to the example of Anonymous. This example is fascinating in the context of our inquiry because most basic features such as organizational membership and boundaries are constantly in doubt. Anonymous is an organized group of 'hacktivists' (i.e. a term that mingles 'hackers' with 'activists'), who engage in collective actions of political and unpolitical nature such as website hacks or street protests. Anonymous activists (also known as “Anons”) describe their organization as a 'collective' or 'hive'. 
Historically, Anonymous emerged as an 'Internet meme' (Blackmore 2000) in online image boards, the most famous being the '4chan image board' in 2006. In an image board, no login is required to post pictures or links to other online content and the default name of a user posting something on the image board is „Anonymous“. In spite of these informal and fluid origins, media coverage of the phenomenon regularly frames Anonymous in organizational terms, calling it, for instance, an "international hacker organization” (e.g., Huffington Post).

The theoretical rationale (Eisenhardt, 1989; Yin, 2009) for choosing Anonymous as a case to investigate organizational identity is that it is an extreme case, i.e. where the identities of an organization's members are deliberately hidden or unknown - often even among different self-declared members of Anonymous. This case selection is guided by Flyvbjerg (2006, p. 229), who asserts that “[a]typical or extreme cases often reveal more information because they activate more actors and more basic mechanisms in the situation studied." So the empirical puzzle in this case is how the organizational identity of Anonymous is constructed given concrete individual human membership is largely invisible, even to the organization itself? Hence, the organizational identity of Anonymous cannot draw on clearly identifiably members but instead, as we assume, very much needs to rely on the performative power of communication practices (Taylor \& Cooren 1997). In other words, if anyone can speak for Anonymous, who cannot speak for Anonymous? By addressing this question with an empirical study we aim to contribute to the theoretical question how organizational identity is formed in contexts of unclear membership and fluid organizational boundaries.

\section{A short history of Anonymous}

Initially, Anonymous was "founded" on the online image board 4chan, or more precisely, on the random board “/b/”, which has a "no rules” policy. As all other boards, /b/ allows only a limited number of threads and new threads replace old ones, which leads to the fact that 
threads disappear on average after 4-6 hours. The first collective activity attributed to Anonymous was called "Habbo Raid", in which 4chan users invaded the Habbo online platform - a mixture of chat and online game frequented mainly by teenagers. The sole motivation for this invasion was fun, the so-called "lulz" (derived from "lol”, which stands for "laughing out loud”). These early activities of Anonymous were very anarchic without any political message and just intended to shock and irritate users of the platform. Thus, the origin of Anonymous was primarily collective "trolling”, which describes intentionally provocative communication (Coleman 2012a).

The unpolitical motivation for collective Anonymous activities changed with the start of the project „Chanology“. Previously, anyone bringing up political issues on 4chan was derided as a „moralfag“. This homophobic language is not uncommon on 4chan - actually everyone on 4chan is called a fag: newbies are „newfags“, experienced users are „oldfags“. In January 2008 someone posted a „call for action“ against censorship practices of the religious sect Scientology on YouTube, which resulted in a series of online protests and, for the first time, also offline protests against Scientology. It was about that time that the Guy Fawkes masks first appeared in the context of Anonymous, enabling "Anons” to take part in offline activities. Guy Fawkes relates to a member of the Gunpowder plot, an attempt to blow up the English Palace of Westminster in London on November 5, 1605; the mask stems from a comic series called "V for Vendetta" inspired by this plot. This first wave of political protests transformed an anarchic mob into an increasingly organized community of 'moralfags', concerned mainly with preserving Internet freedom.

The number of political activities attributed to Anonymous further increased in the course of the Arab spring in early 2011. Furthermore, in what was called "Operation Payback" Anonymous protested against credit card companies and others who have helped the US 
government against the whistleblower platform Wikileaks after it had leaked hundreds of thousands of diplomatic cables (“Cablegate”). At this time, national 'branches' of Anonymous began to emerge, who focused on more local targets. What also began to grow together with the total number of Anonymous activities were the number of incidents, i.e. where the attribution to Anonymous was unclear or challenged. Therefore, it is this last phase that allows us to investigate identity formation and re-production by looking at critical communicative episodes. In the following section, we describe how we identified and collected data on these communicative events as well as how we analyzed this data.

\section{METHODOLOGY}

\section{Data collection}

For our investigation of Anonymous's identity formation from a communication-centered perspective, the main unit of analysis are communicative events (Blaschke, Schoeneborn \& Seidl, 2012), i.e. instances of language use expressed either in verbal or written form that involve at least two individuals and that allow for the mutual negotiation of meaning. Each event of communication, in turn, makes it likely that follow-up communication events will occur (Luhmann, 1992). Through this process, a sequence of interconnected communication events can emerge (i.e. back-and-forth instances of communication such as an email conversation), what we call a “communication episode” (Blaschke et al., 2012, p. 891); in other words, communication episodes are formed by references to past communication events, as expressed in a follow-up communication event (Luhmann, 1992). In organizational contexts, decisions to act as well as actions attributed to the organization are such communicative events. Hence, for analyzing the formation and development of Anonymous as an organizational entity over time, we collected data on communicative episodes attributed to Anonymous as a collective - i.e. organized - actor. 


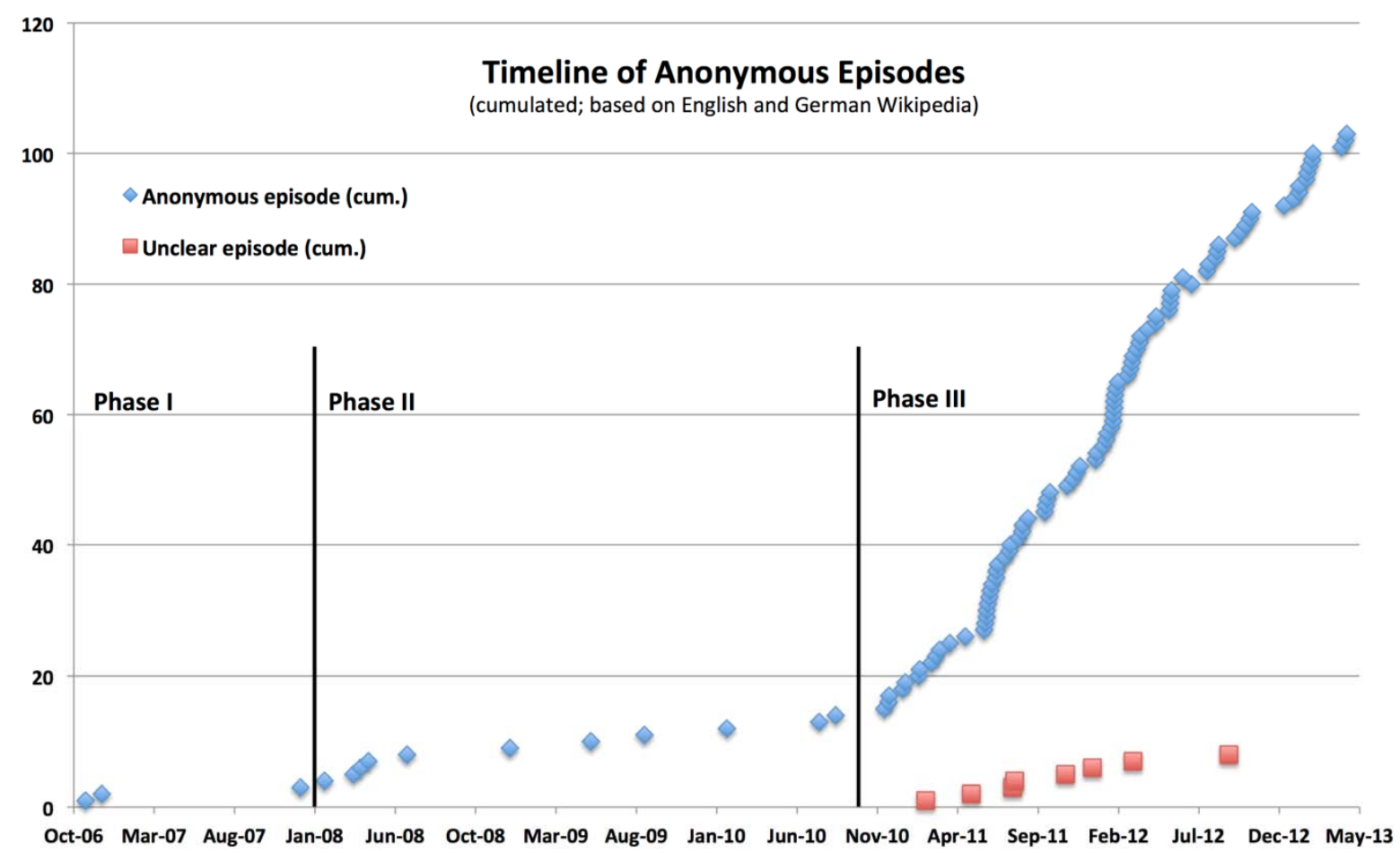

Figure 1: Timeline of Anonymous episodes (cumulated; based on English and German Wikipedia)

For our empirical analysis, we focused on two main data sources. First, we created an episodic case history based upon Anonymous operations listed in the two largest Wikipedia language versions (English and German). Between October 2006 and May 2013 we identified 111 episodes (see Figure 1) and collected links to media reports on each of the respective Anonymous operations referenced in Wikipedia. In this episodic history, we can distinguish three main phases of identity formation characterized by different activity levels: the preformation phase I with few, singular activities, followed by the organizing phase II with first political activities and the still ongoing activism phase III, which features a steep increase in politically and geographically diverse actions (see also Figure 1). In a next step, we evaluated these media reports to assess whether the attribution of the operations to Anonymous was in any way disputed or unclear. By way of this procedure, we identified 8 episodes (out of 111) where the attribution of the episode to Anonymous as an organizational actors was to a certain degree in doubt (see also Table 1). We do not consider these media documents "secondary 
data” since they are instances of those communicative acts that both challenge and constitute the organizational identity we are interested in.

\begin{tabular}{|c|c|c|c|}
\hline Date & Episode & Practices & Why unclear? \\
\hline Feb. 11 & Operation Westboro & $\begin{array}{l}\text { Anonymous supposedly wrote } \\
\text { open letter to the Westboro } \\
\text { Baptist Church }\end{array}$ & $\begin{array}{l}\text { Anonymous subsequently denied the } \\
\text { authenticity of the threat, } \\
\text { suggesting that someone from } \\
\text { outside Anonymous had made the } \\
\text { posting. }\end{array}$ \\
\hline Mai. 11 & $\begin{array}{l}\text { Operation Reasonable } \\
\text { Reaction }\end{array}$ & Pro-Gadhafi hacks & $\begin{array}{l}\text { Anonymous was divided on the } 2011 \\
\text { Libyan civil war }\end{array}$ \\
\hline Jul. 11 & Austrian Greens & $\begin{array}{l}\text { Hacked website and copied data } \\
\text { of } 13.000 \text { users. }\end{array}$ & $\begin{array}{l}\text { AnonAustria claimed to have not } \\
\text { started the hack }\end{array}$ \\
\hline Aug. 11 & Operation Facebook & $\begin{array}{l}\text { According to the links on the } \\
\text { post, Anonymous will take } \\
\text { down Facebook on November } \\
5,2011 \text {. }\end{array}$ & $\begin{array}{l}\text { Anonymous tweeted that they never } \\
\text { announced Operation Facebook and } \\
\text { that this was some guy's idea of a } \\
\text { joke }\end{array}$ \\
\hline Nov. 11 & $\begin{array}{l}\text { Operation Facebook } \\
\text { (Pt. II) }\end{array}$ & $\begin{array}{l}\text { Anonymous exposed initiator of } \\
\text { Operation Facebook }\end{array}$ & $\begin{array}{l}\text { Exposed individual continued to say } \\
\text { it was an Anonymous operation }\end{array}$ \\
\hline Dez. 11 & Attack on Stratfor & $\begin{array}{l}\text { Stole thousands of e-mail } \\
\text { addresses and credit card } \\
\text { information from security } \\
\text { firm Stratfor }\end{array}$ & $\begin{array}{l}\text { Anonymous put out a press-release } \\
\text { stating "This hack is most definitely } \\
\text { not the work of Anonymous" }\end{array}$ \\
\hline Mar-12 & $\begin{array}{l}\text { Symantec source code } \\
\text { leak }\end{array}$ & $\begin{array}{l}\text { Leak of software source code of } \\
\text { Norton Antivirus } 2006\end{array}$ & $\begin{array}{l}\text { Attribution to Anonymous unclear; } \\
\text { Symantec claimed to be } \\
\text { blackmailed }\end{array}$ \\
\hline Sep-12 & Apple UDID leak & $\begin{array}{l}\text { Claim to have stolen } 12 \text { million } \\
\text { Apple UDIDs from the laptop } \\
\text { of an FBI agent; claim later } \\
\text { refuted }\end{array}$ & $\begin{array}{l}\text { Maybe a hoax, owner of data came } \\
\text { out and credibly dismissed FBI } \\
\text { story }\end{array}$ \\
\hline
\end{tabular}

Table 1: Communicative episodes with unclear or disputed attribution to Anonymous

Second, we collected data on communication channels attributed to Anonymous. Figure 2 provides an overview of communication channels attributed to Anonymous with the highest numbers of subscribers (“fans” on Facebook, "followers” on Twitter, etc.). However, these numbers mainly serve illustrative purposes, since other communication channels such as the 4chan image board or AnonNews.org, which allow anyone to post anonymously, do not list subscribers but are of equal, if not greater importance. 


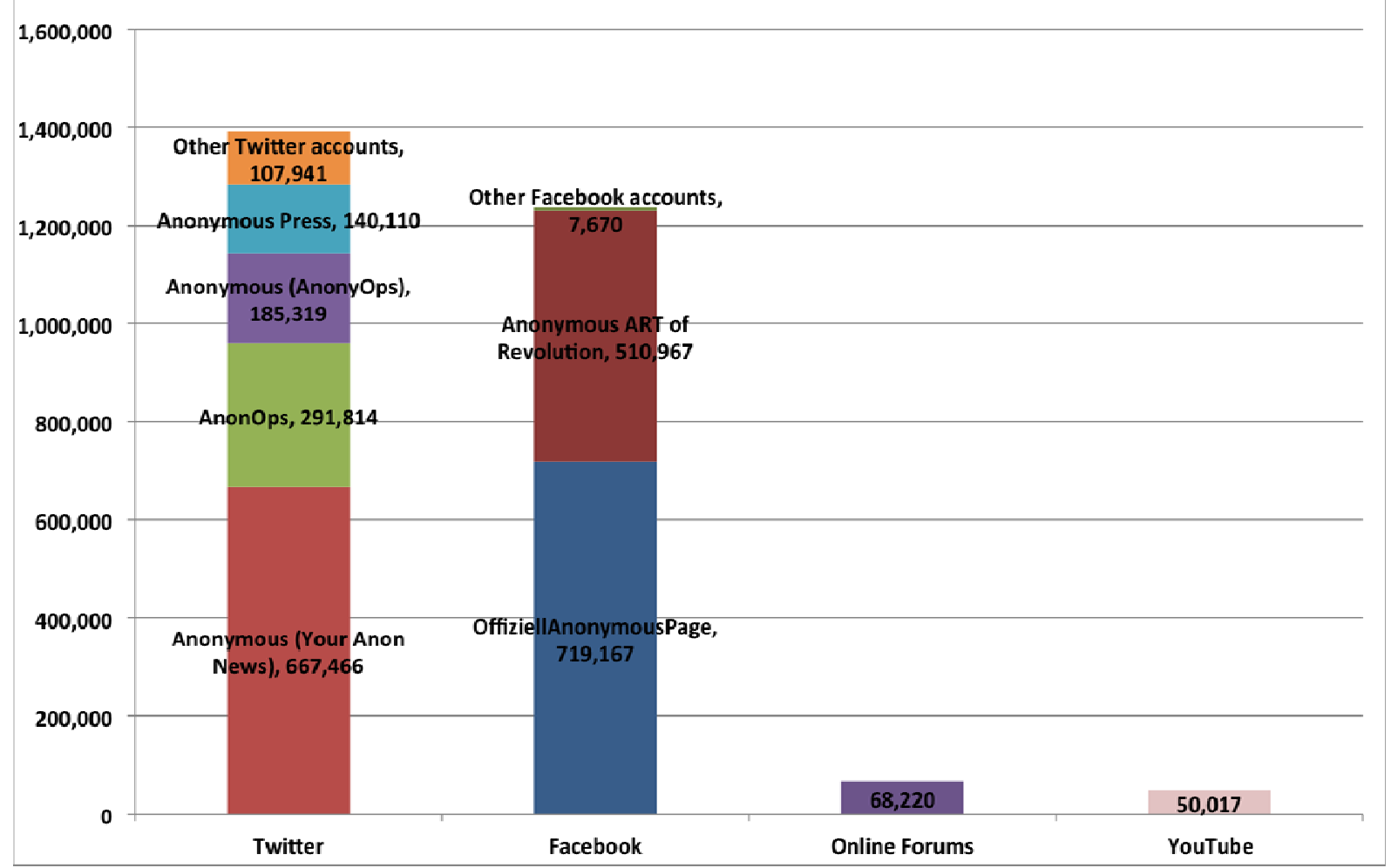

Figure 2: Communication channels attributed to Anonymous with numbers of fans/followers

In our analysis, we did neither include private communication channels nor highly ephemeral types of communication such as online chats (e.g., via Internet Relay Chat; IRC), private email correspondences, or the 4chan image boards, all of which are presumed to be of importance in the context of Anonymous, as well (Coleman, 2012b). While this focus on publicly accessible data is indeed a limitation of our study, there are also two crucial reasons for focusing entirely on publicly available communication - in addition to the pragmatic reason of accessibility: First, for many of its operations Anonymous depends on cooperation and support of actors most of which can only be reached via public broadcast media such as Twitter, Facebook or the press. Second, as we have argued above, identity formation in a hidden and social-movement type organization such as Anonymous particularly depends onpublic communication channels (cf. Morsing, 2006), e.g., where self-declared “Anons” and other actors (e.g. journalists, representatives of targeted organizations, etc.) can take part in identity-constructing communication processes. 


\section{Data analysis}

Our data analysis mainly consists of two parts. As a first step, we chronologically reconstructed the history of Anonymous in a highly condensed description alongside the communicative episodes presented above. We then focused on those eight instances where the attribution of episodes to Anonymous was disputed or unclear and selected two communicative episodes for an in-depth critical analysis: in (1) “Operation Westboro” the Westboro Baptist Church claimed to have received a threat letter by Anonymous, which denied the authenticity of the letter; (2) in "Operation Facebook" someone threatened that Anonymous was going to take down Facebook on November 5 until his identity was exposed. Our main rationale for choosing these two operations was that these were both prominently discussed in the media and only settled over a longer period of public communication. Moreover, the difference in identity claims is of particular interest to our inquiry. While in the case of "Operation Westboro" the identity claim was made by actors undoubtedly external to Anonymous, this very distinction between internal and external actors was at least questioned in the case of "Operation Facebook”.

After having selected these two operations for in-depth investigation, the second part of our data analysis consisted in reconstructing a timeline of public communication events for each of the episodes. To conduct this analysis, we returned to our two main data sources - i.e. media coverage on operations and communication channels attributed to Anonymous - as starting points for communication events referring to the two episodes of interest. 


\section{FINDINGS}

For each of the critical episodes under study we have assembled a table with core passages of communication events in chronological order. In addition to these tables, we provide further context on selected communicative events and the main actors and communication channels respectively.

\section{Critical Episode I: Operation Westboro}

The Westboro Baptist Church (WBC) is a US-American, independent religious community known for extreme ideological positions and respective activities such as running the homophobic website www.godhatesfags.com. On February 19, 2011, a WBC spokeswomen announced via Twitter that the WBC had received a threatening open letter by Anonymous and published a response letter entitled “Bring it!”, which denounced Anonymous as “Coward Crybaby 'Hackers'”. The open letter addressed to the WBC had been posted to the website AnonNews.org, which allows anyone to publish without registration or any other form of authentification and is regularly used for distributing information regarding Anonymous such as press releases.

After having been picked up and attributed to Anonymous by established news media outlets such as CBS News, Anonymous renounced authorship of the open letter the following day. A press release, which was also posted to AnonNews.org, accused WBC of having faked the open letter and explicitly addressed both media actors as well as self-identified members of Anonymous. While the press release lectured the former that "[j]ust because it was posted on AnonNews doesn't mean every single Anon is in agreement”, it warned fellow “Anons” that 
WBC might have set up a trap to make money by suing anyone taking part in distributed denial of service (DDoS) attacks. ${ }^{1}$

News media were left puzzled with this situation and struggled with the question who was allowed to speak on behalf of Anonymous. The online magazine Salon.com, for example, explicitly asked "why should the second open letter be given any more credence than the first?” on February 21. This question was particularly salient since in the following days WBC websites actually were subject to attacks. However, three days after the article in Salon.com, a self-declared member gave a live interview to radio talk show host David Pakman in which he credited a hacker named "The Jester" for these attacks and again denounced any involvement of Anonymous. To support this claim, he mentioned that the initial open letter had come out of nowhere and that "it doesn't seem the writing style we would make. Nobody that usually writes press releases stood up and said: 'Hey, we wrote this." Table 2 gives an overview and provides more detailed quotes on how this communicative episode unfolded.

While the authorship of the initial open letter has never been definitely clarified, the episode was not the last encounter of the WBC and Anonymous. Nearly two years later, in December 2012, Anonymous released the names, addresses, and e-mails of prominent WBC members due to announced plans to picket the funerals of the victims of the Sandy Hook Elementary School shooting. This time, however, no one challenged the attribution to Anonymous. In a way, the Operation Westboro episode taught external actors such as media commentators to distinguish between different communication channels as a means of attributing

\footnotetext{
${ }^{1}$ In a DDoS attack a large and coordinated number of computers try to reach a certain web servers until it is overloaded with connections and can therefore no longer be reached by other users.
} 
communication to Anonymous, which can be observed in the next episode under study, as

well.

\begin{tabular}{cl}
\hline Date & Communication Event \\
\hline February 16, & Open Letter to Westboro Baptist Church: "We, the collective \\
super-consciousness known as ANONYMOUS - the Voice of \\
Free Speech \& the Advocate of the People - have long heard \\
you issue your venomous statements of hatred, and we have \\
witnessed your flagrant and absurd displays of inimitable \\
bigotry and intolerant fanaticism. [...] Thus, we give you a \\
warning: Cease \& desist your protest campaign in the year \\
2011, return to your homes in Kansas, \& close your public Web \\
sites. Should you ignore this warning, you will meet with the \\
vicious retaliatory arm of ANONYMOUS: We will target your \\
public Websites, and the propaganda \& detestable doctrine \\
that you promote will be eradicated;"
\end{tabular}

February 19, Tweet pointing to News release: "Open Letter from WBC to

2011 Anonymous http://bit.ly/gXEv1r@AnonymousIRC @OfficialAnonOps@Anony_Ops"

Westboro Baptist Church News release: "Open Letter from Westboro Baptist Servants of God to Anonymous Coward Crybaby 'Hackers': Bring it! [...] Anonymous is warring with God; very stupid for little boys claiming to be smart."

February 19, Hackers warn Westboro Church: Stop now or else: "A group of 2011 hacktivists acting under the banner, 'Anonymous,' has warned a church with a controversial history that unspoken retribution will follow it continues its practice of inflammatory protests. In an open letter to the Westboro Baptist Church, Anonymous has put the anti-gay, fundamentalist church on notice that 'the damage incurred will be irreversible,' and that 'neither your institution nor your congregation will ever be able to fully recover."'

February 20, Anonymous Press Release: "So we've been hearing a lot about 2011 some letter that we supposedly sent you this morning. Problem is, we're a bit groggy and don't remember sending it. Our best guess is that you heard about us on that newfangled TV of yours and thought we might be some good money for your little church. [...] To the Media: Just because it was posted on AnonNews doesn't mean every single Anon is in agreement, in fact in this case it doesn't even mean a single Anon is in agreement. [...] To Anonymous: It's a trap. They've got their ports wide open to harvest IPs to sue. Don't DDoS, and boycott Operation Westboro."

February 21, Is the Anonymous-Westboro Baptist Church feud a hoax?: "Then 2011 things got weirder. Another 'open letter' appeared on AnonNews - the website is built on an 'open-posting' concept, meaning anyone is free to publish anything there - claiming that the first letter did not represent the will of the infamous 'hacktivists.' [...] However, some aspects of the "hoax" theory seem iffy. To start, if stories on AnonNews don't necessarily reflect the will of Anonymous, why should the second open letter be given any more credence than the first? Even if some members of Anonymous denounced the Westboro plot, the organization is more a loose agglomeration of individuals than

Twitter, https://twitter.co $\mathrm{m} /$ meganphelps/status/39161975502020608

CBS News, http://www.cbsnews.com/8301501465_16220033942501465.html

AnonNews, http://anonnews.org/?p=pres $s \& a=i t e m \& i=494$

Salon.com, http://www.salon.com/2011/02/21/anonymous_westboro_church_hoax / 
there does appear to be some form of organizational hierarchy, the group is still largely amorphous to the public eye.)"

February 24, Radio interview with a self-declared member of Anonymous:

2011 "With most operations we have planning, we have execution, we have discussion of it. This press release came out of nowhere and it doesn't seem the writing style we would make. Nobody that usually writes press releases stood up and said: 'Hey, we wrote this.' The operation came out of nowhere and you guys [i.e. Westboro Baptist Church] responded really too fast. It was all a bit suspicious. [...] We didn't attack your websites. It was another hacktivist. [WBC intervention: "Potato-potato. You are all a bunch of criminals, and thugs, and you are disobedient and extreme and you don't obey god. And you are all facing your imminent destruction."] The four or five [websites] that are down were not our doing. These were the doings of another hacktivist that goes by the name of Jester [...] Our response was mature. It was 'we don't want to go to war with you, we are busy with Operation Freedom.' [...] I have a surprise for you. [...] If you check downloads dot westborobaptistchurch dot com right now, you will see a nice message from Anonymous."

February 24, Anonymous hacks church Web site during live interview: "The 2011 Anonymous hacking collective this morning defaced the Web

site of the controversial Westboro Baptist Church in the middle of a live radio show that included a church spokeswoman and a member of Anonymous. [...] Prior to today's attacks, WBC's sites were offline for several days. That outage appears to have been caused by a distributed denial of service attack launched by a hacker called The Jester. A note posted by Anonymous on the newly defaced WBC site this morning said that the church's 'recent antics to gain media attention,' had caused the group to lose patience with the church."

Table 2: Chronology of communication events in the critical incident "Operation Westboro"

Computerworld, http://www.computerworld.com/s/article/9211305/Anonymous_hacks_church_Web_site_during_live_interview
Show, http://www.youtube.com/watch?v=0ZJwSjor4 $\mathrm{hM}$

\section{Critical Episode II: Operation Facebook}

The critical episode "Operation Facebook" consists of two sub-episodes, one in August and another one in November 2011. In August 2011, a group claiming to be part of Anonymous declared a "war on facebook" and announced an upcoming attack on November 5, 2011, i.e. on Guy Fawkes Day. While initially the authenticity of "Operation Facebook” was renounced all together via the Twitter account “AnonOps” (“TO PRESS: [...] \#OpFacebook is just ANOTHER FAKE!”), a few hours later another tweet stated that “\#OpFacebook is being organised by some Anons. This does not necessarily mean that all of \#Anonymous agrees with it.” Prior to these announcements, several anonymous actors had collaborated in crafting 
the threat letter in a public "Pirate Pad" - an online tool that enables anonymous collaborative writing (see Table 3).

Not least due to the prominence of the target, the social media platform Facebook, media outlets quickly reported on the threat, albeit being more cautious compared to the Westboro case described above. Specifically the fact that "\#OpFacebook" had been announced on a separate Twitter account seemed suspicious. The Washington Post, for instance, considered the account "AnonOps” to be a more credible communication channel, calling it "a more mainstream Anonymous Twitter account.”

Following the initial publication of the threat letter, the OpFacebook Twitter account regularly featured tweets (i.e. Twitter postings) emphasizing that “Operation Facebook” was not a fake: “Are we fake?: No, our group of anons have been loyal for 4-5+ years.” However, on November 4, 2011, before the takedown of Facebook was supposed to happen, activists of Anonymous exposed the originator of the threat to demonstrate that "\#OpFacebook" was in fact not supported by Anonymous, as Cnet reported:

“One skiddy queer chap named Anthony [last name redacted] from the US in Ohio decided to take it upon himself to have some lulz with creating an imaginary opfacebook and pawning it off as a legit anon op,” the statement said. "Despite us telling this mate several times we did not support his op, he continued to push his agenda for lulz. This op is phony but he continues to say it’s an anon op.”

In other words: members of Anonymous decided to expel another member by lifting the veil of anonymity and exposing his identity to the public (see again Table 3 for an overview and detailed quotes of the communication events). 


\begin{tabular}{|c|c|}
\hline Date & Communication Event \\
\hline $\begin{array}{c}\text { June } 30- \\
\text { August } \\
9, \\
2011\end{array}$ & $\begin{array}{l}\text { Collaborative crafting of press release for Operation Facebook; } \\
\text { Screenshot June 30, Version } 2102 \text { (different colors represent } \\
\text { different anonymous authors): } \\
\text { Facebook has been selling information to the TSA and giving clandestine } \\
\text { access to information security firms so that they can spy on people from all } \\
\text { around the world. Some of these so-called whitehat infosec firms are } \\
\text { working for authoritarian governments, such as those of Egypt and Syria. } \\
\text { How would you know that your isn't being monitored and the information } \\
\text { handed over to someone who may come after you? Everything you do on } \\
\text { Facebook stays on Google regardless of your "privacy" settings, and } \\
\text { deleting your account is impossible -- even if you "create" your account, all } \\
\text { your personal info stays on Facebook and can be recovered at any time. } \\
\text { Changing the privacy settings to make your Facebook account more } \\
\text { "private" is also a delusion, Facebook knows more about you than your dog. }\end{array}$ \\
\hline
\end{tabular}

August 9, Anonymous press release: "Attention citizens of the world, We 2011 wish to get your attention, hoping you heed the warnings as follows: Your medium of communication you all so dearly adore will be destroyed. If you are a willing hacktivist or a guy who just wants to protect the freedom of information then join the cause and kill facebook for the sake of your own privacy. [...]Think for a while and prepare for a day that will go down in history. November 5 2011, \#opfacebook . Engaged."

August 9, Anonymous Vows to 'Destroy' Facebook on Nov. 5: "Anonymous 2011 has vowed to 'destroy' Facebook on Nov. 5. Or more accurately, somebody has set up a Twitter account and YouTube channel to announce a plan dubbed 'Operation Facebook.' With the loosely affiliated hacktivist collective, it's always tough to know what's real, what's a feint, and what's a solo effort by some ambitious Anon to marshal the troops."

August 10 , 2011

"TO PRESS: MEDIAS OF THE WORLD... STOP LYING! \#OpFacebook is just ANOTHER FAKE! WE DONT "KILL" THE MESSENGER. THAT'S NOT OUR STYLE \#Anonymous"

"\#OpFacebook is being organised by some Anons. This does not necessarily mean that all of \#Anonymous agrees with it."

August 10 , 2011
Facebook 'operation' shows off Anonymous's cracks: “A group claiming to be part of the hacktivist collective Anonymous has declared war on Facebook - but they shouldn't expect the support of the majority of their peers. On a more mainstream Anonymous Twitter account, AnonOps, members of the group said that the announced attack on Facebook does not represent the views of all its members. [...]In a May report in the Financial Times, an established Anonymous hacker nicknamed Kayla addressed this issue. 'If you say you are Anonymous, and do something as Anonymous, then Anonymous did it,' the hacker told the newspaper. 'Just because the rest of Anonymous might not agree with it doesn't mean Anonymous didn't do it.' There are, however, some signs that the loose nature of the group is starting to grate on the nerves of more established members. 'The old hats of Anonymous have decided to take stronger hold of the reins,' a message on another Anonymous Twitter account, AnonyOps, read, after messages disowning the Facebook attack. 'We're taking Anon back. Time for sensible, focused discussion.'
Communication

Channel

PiratePad, http://piratepad.ne t/ep/pad/view/YCPcpwrl09/latest

Piratepad, http://piratepad.ne t/YCPcpwrl09

PC Magazine, http://www.pcmag.com/article2/0,2817,2390768,00.asp

Twitter, https://twitter.com/anonops/status/101152229087657984; https://twitter.com/anonops/status/101194056008351744

Washington Post, http://www.washingtonpost.com/blogs/faster-forward/post/facebookoperation-showsoff-anonymousscracks/2011/08/10/gIQAL55A7I_blog.html 
August

29 ,

2011

"Questions Answered.

1. Are we fake?: No, our group of anons have been loyal for 4-5+ years.

2. Are we going to... http://fb.me/12lNwi0Do"

October 7, "Just hit 1000 known groups of 5 people or more who know the 2011 flaw in FB's security. 5000+ people will be attacking on the 5th. We WILL win."

Novembe "Countdown engage. Three days remaining till facebook has no r 2, face left. Please enjoy the fireworks, and make sure...

2011 http://fb.me/yWx7l9UR"

Novembe Anonymous says Facebook attack was never real: "Members of r 4 , 2011

Novembe

r 5 , 2011
Anonymous fed up with reports that the online activist group is going to take down the social network said today that the threat is not real and was the work of one lone member without any support from others in the group. They said it doesn't make sense to shut down a site they use to get their message out. [...] 'One skiddy queer chap named Anthony [last name redacted] from the US in Ohio decided to take it upon himself to have some lulz with creating an imaginary opfacebook and pawning it off as a legit anon op," the statement said. "Despite us telling this mate several times we did not support his op, he continued to push his agenda for lulz. This op is phony but he continues to say it's an anon op.' The statement then provides an address, phone number, and other information ostensibly belonging to the individual named."

Update November 5 at 11:56 a.m. PT: "In an an-email exchange with CNET, Anthony said he did not launch OpFacebook; he merely created the OpFacebook page on Facebook and populated it with information from other sources. 'I have been used as a scape goat, nothing more nor less,' he said. [...] 'Because I had the balls to go out of my way and provide people with information that I found about the \#0p, I was used as a scape goat of sorts when Anonymous figured out they could not ACTUALLY take down Facebook.'”
Twitter,

https://twitter.com /OpFacebook/status/107997996066680832

Twitter, https://twitter.com/OpFacebook/status/122259706646495232

Twitter, https://twitter.com /OpFacebook/status/131847518559535107

Cnet, http://news.cnet.com/830127080_3$57319073-$ 245/anonymoussays-facebookattack-was-neverreal/

Cnet (Update), http://news.cnet.com/830127080_357319073245/anonymoussays-facebookattack-was-neverreal/

Table 3: Chronology of communication events in the critical incident "Operation Ourabora"

\section{DISCUSSION}

As our empirical study of the Anonymous case has shown, even the most fluid forms of organization (Schreyögg \& Sydow, 2010 with a very limited ability to decide on membership (Ahrne \& Brunsson, 2011), tend to exhibit practices of identity formation and boundary maintenance. In this case, the organizational boundary was continuously maintained through public negotiation whether a communicative event can be attributed to the organization or not (Cooren, 2012; McPhee \& Zaug, 2009). From the two critical episodes that challenged the 
organizational identity and boundary of Anonymous (Operation Westboro and Operation Facebook), we can distill a pattern of communicative mechanisms that evidently can serve as a functional equivalent and substitute to member-based identity formation. Further research will need to explore the boundary conditions under which this pattern is likely to occur in comparable organizational settings.

\section{1st degree of communicative boundary maintenance:}

\section{Drawing on functionally equivalent resources of identity}

The recent history of Anonymous has featured a steep increase in hacker activities that can be attributed to the organization (see Figure 1). However, at the same time, this development cooccurred with the first appearance of "unclear" activities that were subject to public debates on whether these episodes could be attributed to Anonymous or not. As our analysis of the Operation Westboro case has shown, in a situation where identifiable membership is missing as a reference point of identity formation (or, in the terminology of Luhmann, 2000, as a decision premise for the organization and its external constituents), other communicative practices may function as alternative reference points for identity formation. In this episode, publicly accessible debates mainly focused on which communication channels can ensure most reliably and credibly who is allowed to speak on behalf of the organization or not (Cooren, 2012). In other words, not only membership negotiations but also other decision premises such as recurrent use of certain communication channels can serve as important anchors or resources for identity construction.

However, our processual and communication-centered view on organizations (Ashcraft et al., 2009; Cooren et al., 2011) reminds us that, in turn, the communication channel's reliability as a reference point is not a given but instead needs to be continuously re-accomplished through practices of communicative attribution. Hence, as a comparison of Operation Westboro and 
Operation Facebook shows, that the credibility of a communication channel depends on its specific history. In the Westboro case, the communication channel AnonNews.org was questioned because it could not reliably provide any authentication whether the announcements via this channel were consistent with previous communicative events attributed to Anonymous. Hence, the identity crisis was resolved with the help of another communication channel - a live radio interview - where authenticity claims were substantiated with communicative action in form of a website hack. This episode therefore demonstrates that the meaning of past communication events tends to be interpreted in the light of follow-up communication event, e.g., by subverting or substantiating the meaning that was previously attributed to the communication event (Luhmann, 1992). In the Facebook case, in turn, media observers granted varying degrees of credibility to Twitter accounts by pointing to the respective communication history. New accounts were therefore considered to be less credible sources than "more mainstream" accounts with a history of communication that previously had led to action. The identity crisis of Anonymous in the Facebook episode, which resulted from repeated calls to action by the newly founded communication channel “opfacebook”, seems to have created fertile ground for the emergence of a $2^{\text {nd }}$ degree of communicative boundary maintenance, which is presented in the next section.

\section{2nd degree of communicative boundary maintenance:}

\section{The performative power of excommunication}

As shown by our second case, Operation Facebook, Anonymous became challenged by activities that failed to have "authoritative" status (Kuhn, 2008), i.e. where their alignment with the goals of the organizational endeavor was publicly put into question. Strikingly, and in addition to communication channels as a reference points for identity formation, we observed the emergence of a new and further escalated practice of communicative boundary 
maintenance: By “flipping” (i.e. de-anonymizing) the previously anonymous identity of the hacker who had initiated the discredited "Operation Facebook", members of Anonymous literally mobilized the performative power of "excommunication”. In other words, they banned the attribution of a communicative episode to Anonymous as an organization by publicly identifying and expelling one individual hacker.

We believe that the emergence of this new practice is most interesting in the context of our inquiry for two reasons: First, given that the communicative constitution of Anonymous as an organization is strongly centered on the anonymity of its members, the mere public disclosure of a hacker's identity is sufficient to make it impossible for this individual to further belong to the organizational endeavor. In this regard, it represents an "excommunication" in the most literal and historical sense. Leveraging the performativity of language use, a new state of affairs was created through the very utterance itself (cf. Taylor \& Cooren, 1997). For hidden organizations such as Anonymous (Scott, 2013) this practice of de-anonymization can also be seen as a "maximum penalty" for the individual hacker and a "last resort" of boundary maintenance of the organization given that future contributors to the cause may always run the risk of becoming "flipped".

Second, in this case, the organization as a communicative entity seems to have been only able to restore its identity at the expense of an individual's identity. From the CCO view, and especially the Luhmannian stream of CCO thinking (e.g., Seidl, 2007), this can indicate a close structural coupling between organizational and individual identity more generally. However, we need to consider, that the "flipping” of the hacker's identity was only possible because his identity was known at least to some members of the organization. Interestingly, while in organizations such as Anonymous, there is no possibility to decide on the inclusion of members (as individual actors can join the organizational endeavor through self- 
identification), the exclusion of members indeed is possible (as shown through the “excommunication practice”). Due to this asymmetry between entry and exit, we would argue that Anonymous case exhibit an “inverse” membership negotiation (McPhee \& Zaug, 2009) where the weight solely lies on exclusion rather than inclusion,

Across episodes, we can see that both forms of communicative boundary maintenance took place in the public arena and the credibility of communicative events was substantiated by subsequent actions such as website hacks. This reconfirms the core claim of a CCO perspective that reproduction not only of organizational identity but of organizational structures more generally requires follow-up communication. Instances of such follow-up communication may be either events of performative language use or performance of actions referenced in a respective communicative episode (Luhmann, 2000; Seidl, 2007). As the case of Anonymous shows, follow-up communication such as hacking a website during a radio interview or revealing the identity of self-declared “Anon” effectively resolved an identity, thereby performatively re-instating organizational boundaries.

Finally, in line with the findings by Morsing (2006), organizations with unclear membership status rely on auto-communication and self-assurance in order to successfully maintain their identity. Again, this finding points to the intertwined nature of both (internal) identity and (external) image, as also emphasized by Kjaergaard et al. (2011). Highly fluid and hidden organizations such as Anonymous seem to depend on instances of extreme visibility (as in the case of al Qaeda; cf. Schoeneborn \& Scherer, 2012) in order to perpetuate their existence. By being mirrored in public communication, organizations of this kind can become stabilized even in the wake of fluidity in that image furthers identity. While this pattern is particularly salient in extreme organizational cases such as Anonymous, we believe that that the performative power of public communication for organizational identity formation also 
applies to organizations more generally (cf. the notion of "aspirational talk” by Christensen et al., 2013).

\section{CONCLUSION}

In this paper, by transcending membership-centered views on organizational identity, we apply a communication-based framework to explain identity formation and maintenance in fluid organizational settings. Our analysis of the case of Anonymous has shown how an organizational identity can be uphold even when membership is unclear or highly unstable. Insofar membership is in doubt, functional equivalents to membership such as communication channels with a history of credible communication may serve as means for attributing communication to an organization. This importance of attributing communication by third parties underlines, in turn, the critical role of external actors in the communicative construction of organizational identity.

Our study makes the three main theoretical contributions to the existing literature: First, we demonstrate how organizational identity emerges from and is reproduced within a continuous stream of communicative events, thereby transcending essentialist views on identity (Gioia et al. 2013). Such a communication-centered perspective underlines that identity is inherently precarious, because identity claims always rely on confirmation by follow-up communication. As soon as this follow-up communication is inconclusive or outright contradictory, we will observe an identity crisis. While the precarious nature of identity formation has been recognized already by processual views on identity construction (Schultz \& Hernes 2013), we show how follow-up communication may change the meaning of past communication events during a communication episode. Having demonstrated this phenomenon in the special case of Anonymous, we deem this insight to be a more general one, applicable also in the realm of corporate scandals (see, for example, Kuhn \& Ashcraft 2003). 
Second, this communication-centered perspective allows us to overcome the duality of identity and image prevalent in the literature. Follow-up communication substantiating or subverting identity claims regularly involves external actors such as peer organizations Gioia et al. 2010) or the media (Kjaergaard et al. 2011; see also Gioia et al. 2013: 163ff.). And while such external actors and other external influence factors may be particularly important in the case of Anonymous, we again try to make a more general point here. Focusing on communicative events and episodes allows for an integration of different sources of identityrelated communication, effectively tearing down the conceptual wall between identity and image in the literature.

Third, in our investigation of Anonymous, we were able to distill mechanisms of performative excommunication even in highly fluid organizational settings (Schreyögg \& Sydow 2010). This finding leads us to question the relevance attributed a priori to selected forms of communication such as membership negotiations in some strands of CCO thinking (see, for example, McPhee \& Zaug, 2009). As the case of Anonymous shows, admission may be less important than the power to excommunicate to uphold organizational boundaries. What counts is that the attribution of a communication event is substantiated by follow-up communication, which again emphasizes the processual and non-essentialist nature of a communication-centered perspective on identity formation. And even though we share this processual view with other scholars, our focus on communication episodes allows us to go beyond processual views that continue to strongly rely on the notion of individual human membership (e.g., Schultz \& Hernes, 2013).

We firmly believe that the Anonymous case can be utilized as a fertile ground for further conceptual and empirical inquiries into the communicative nature of organizational identity formation and boundary maintenance. The case of course particularly lends itself to extend its 
findings and to cross-validate the identified process pattern in similar organizational settings of fluid organizations that operate largely in hidden form (Scott, 2013), for instance, al Qaeda (Schoeneborn \& Scherer, 2012; Stohl \& Stohl, 2011) or, to a certain degree, the Mafia (Gambetta, 2009). However, future research will also need to further illuminate the communicative dimension of identity formation in much more conventional organizational settings. In such context, we deem it promising to investigate the role of public and external communication also for the internal formation of identity (similar to Kjaergaard et al., 2011) an issue that becomes especially prevalent for organizations of all kinds in the age of social media (Kjaergaard \& Morsing, 2012). 


\section{REFERENCES}

Albert, S., Ashforth, B.E., and Dutton, J.E. (2000). 'Organizational identity and identification: Charting new waters and building new bridges'. Academy of Management Review, 25, 1317.

Albert, S. and Whetten, D.A. (1985). 'Organizational identity', in L.L. Cummings \& M.M. Staw (Eds.), Research in organizational behavior. Greenwich, CT: JAI, 263 - 295.

Ahrne, G. and Brunsson, N. (2011). 'Organization outside organizations: the significance of partial organization’. Organization, 18, 83-104.

Ashcraft, K. L., Kuhn, T. R. and Cooren, F. (2009). 'Constitutional Amendments: “Materializing” Organizational Communication’. The Academy of Management Annals, 3, $1-64$.

Ashforth, B.E. and Mael, F. (1989). 'Social identity theory and the organization'. Academy of Management Review, 14, 20-39.

Ashforth, B.E., Rogers, K.M. and Corley, K.G. (2011). 'Identity in organizations: Exploring cross-level dynamics’. Organization Science, 22, 1144-1156.

Benner, M.J. (2007). 'The incumbent discount: Stock market categories and response to radical technological change'. Academy of Management Review, 32, 703-720.

Blackmore, S. (2000). The Meme Machine. Oxford: Oxford University Press.

Blaschke, S., Schoeneborn, D. and Seidl, D. (2012). 'Organizations as networks of communication episodes: Turning the network perspective inside out'. Organization Studies, 33, 879-906.

Brown, A.D. and Starkey, K. (2000). 'Organizational identity and organizational learning: A psychodynamic perspective’. Academy of Management Review, 25, 102-120.

Brummans, B., Cooren, F., Robichaud, D. and Taylor, J. R. (forthcoming). 'Approaches in research on the communicative constitution of organizations', in L. L. Putnam, \& D. 
Mumby (Eds.), Sage handbook of organizational communication (3rd ed.). London, UK: Sage.

Christensen, L.T. and Cornelissen, J. (2011). 'Bridging Corporate and Organizational Communication: Review, Development and a Look to the Future'. Management Communication Quarterly, 25, 383-414.

Christensen, L. T., Morsing, M. and Thyssen, O. (2013). 'CSR as aspirational talk'. Organization, 20, 372-393.

Coleman, G. (2012a). 'Phreaks, Hackers, and Trolls: The Politics of Transgression and Spectacle’, in: Mandiberg, M. (Eds.), The Social Media Reader. New York: New York University Press, 99-118.

Coleman, G. (2012b). Our weirdness is free: the logic of Anonymous - online army, agent of chaos, and seeker of justice'. Triple Canopy, 15, Online: http://canopycanopycanopy.com/15/our_weirdness_is_free (May 26, 2013)

Cooren, F. (2012). 'Communication theory at the center: Ventriloquism and the communicative constitution of reality’. Journal of Communication, 62, 1-20.

Cooren, F., Kuhn, T., Cornelissen, J. and Clark, T. (2011). 'Communication, organizing, and organization: An introduction to the special issue'. Organization Studies, 32, 1149-1170.

Cornelissen, J.P., Clarke, J.S. and Cienki, A. (2012). 'Sensegiving in entrepreneurial contexts: The use of metaphors in speech and gesture to gain and sustain support for novel business ventures’. International small business journal, 30, 213-241.

Craig, R. T. (1999). 'Communication theory as a field’. Communication Theory, 9, 119-161.

Czarniawska, B. (1997): Narrating the Organization: Dramas of Institutional Identity. Chicago: University of Chicago Press. 
Deetz, S. (1994). 'The future of the discipline: The challenges, the research, and the social Contribution', in S. Deetz (Ed.), Communication yearbook, vol. 17 (pp. 565-600). Thousand Oaks, CA: Sage.

Dutton, J. E. and Dukerich, J. M. (1991). 'Keeping an eye on the mirror: Image and identity in organizational adaptation’. Academy of Management Journal, 34, 517-554.

Fairhurst, G. (2007). Discursive leadership: In conversation with leadership psychology. Thousand Oaks, CA: Sage.

Fiol, C. M. and Romanelli, E. (2012). 'Before Identity: The Emergence of New Organizational Forms’. Organization Science, 23, 597-611.

Flyvbjerg, B. (2006). 'Five Misunderstandings About Case-Study Research’. Qualitative Inquiry, 12, S. 219-245.

Gambetta, D. (2009). Codes of the underworld: how criminals communicate. Princeton, NJ: Princeton University Press.

Gatewood, R. D., Gowan, M. A. and Lautenschlager, G. J. (1993). 'Corporate Image, Recruitment Image, and Initiatial Job Choice Decisions’. Academy of Management Journal, 36, 414-427.

Giddens, A. (1984). The Constitution of Society: Outline of the Theory of Structuration. Berkely: University of California Press.

Gioia, D.A., Patvardhan, S.D., Hamiltoon, A.L. and Corley, K.G. (2013). 'Organizational Identity Formation and Change’. The Academy of Management Annals, 7, 123-192

Gioia, D.A., Price, K.N., Hamilton, A. L. and Thomas, J.B. (2010). 'Forging an Identity: An Insider-outsider Study of Processes Involved in the Formation of Organizational Identity’. Administrative Science Quarterly, 55, 1-46.

Gioia, D.A. and Thomas, J.B. (1996). 'Identity, image, and issue interpretation: Sensemaking during strategic change in academia’. Administrative Science Quarterly, 41, 370-403. 
Glynn, M.A. and Watkiss, L. (2012). 'Exploring cultural mechanisms of organizational identity construction', in M. Schultz, S. Maguire, A. Langley, \& H. Tsoukas (Eds.), Constructing identity in and around organizations. New York: Oxford University Press, $63-88$.

Hatch, M.J. and Schultz, M. (2000). 'Scaling the Tower of Babel: Relational differences between identity, image and culture in organizations', in Schultz, M., Hatch, M.J., \& Larsen, M.H. (Eds.), The Expressive Organization : Linking Identity, Reputation, and the Corporate Brand. Oxford: Oxford University Press, 11-35.

Hernes, T. (2008). Understanding Organization as Process: Theory for a Tangled World. New York: Routledge.

Heumer, L., Becarra, M. and Lunnan, R. (2004): 'Organizational identity and network identification: relating within and beyond imaginary boundaries'. Scandinavian Journal of Management, 20, 53-73.

Jack, G. and Lorbiecki, A. (2007). 'National identity, globalization and the discursive construction of organizational identity’. British Journal of Management, 18, 79 - 95.

Kjærgaard, A. and Morsing, M. (2012). From liberating technologies to cultural engineering - a case study of how social media guidelines are used to discipline employee behaviour. Paper presented at the European Group of Organizational Studies Colloquium (EGOS), July 5-7, 2012, Helsinki, Finland.

Kjaergaard, A., Morsing, M. and Ravasi, D. (2011): 'Mediating Identity: A Study of Media Influence on Organizational Identity Construction in a Celebrity Firm'. Journal of Management Studies, 48, 514-543

Kroezen, J.J. and Heugens, P.P.M.A.R. (2012). 'Organizational identity formation: Processes of identity imprinting and enactment in the Dutch microbrewing landscape', in M. Schultz, 
S. Maguire, A. Langley, \& H. Tsoukas (Eds.), Constructing identity in and around organizations (pp. 89 - 127). Oxford: Oxford University Press.

Kuhn, T. R. and Ashcraft, K. L. (2003). 'Corporate scandal and the theory of the firm: Formulating the contributions of organizational communication studies'. Management Communication Quarterly, 17, 20-57.

Kuhn, T. (2008). 'A communicative theory of the firm: Developing an alternative perspective on intra-organizational power and stakeholder relationships'. Organization Studies, 29, $1227-1254$.

Langley, A. (1999). 'Strategies for theorizing from process data'. Academy of Management Review, 24, 691-710.

Luhmann, N. (1992). 'What is communication?’. Communication Theory, 2, 251-259.

Luhmann, N. (2000). Organisation und Entscheidung. Opladen: Westdeutscher Verlag.

Mohe, M. and Seidl, D. (2011). 'Theorizing the client-consultant relationship from the perspective of social-systems theory’. Organization, 18, 3-22

Nassehi, A. (2005). 'Organizations as decision machines: Niklas Luhmann's theory of organized social systems’. Sociological Review, 53, 178-191.

McPhee, R. D. and Zaug, P. (2009). 'The communicative constitution of organizations: A framework for explanation', in L. L. Putnam, \& A. M. Nicotera (Eds.), Building theories of organization: The constitutive role of communication (pp. 21-48). New York, NY: Routledge.

Morsing, M. (2006). 'Corporate social responsibility as strategic auto-communication: on the role of external stakeholders for member identification'. Business Ethics: A European Review, 15, 171-182.

Porac, J.F., Wade, J.B. and Pollock, T.G. (1999). 'Industry categories and the politics of the comparable firm in CEO compensation’. Administrative Science Quarterly, 44, 112 - 144. 
Putnam, L. L. and Nicotera, A. M. (Eds.). (2009). Building theories of organization: The constitutive role of communication. New York, NY: Routledge.

Ravasi, D. and Schultz, M. (2006). 'Responding to organizational identity threats: Exploring the role of organizational culture'. Academy of Management Journal, 49, 433-458.

Ravasi, D. and van Rekom, J. (2003). 'Key Issues in Organizational Identity and Identification Theory’. Corporate Reputation Review, 6, 118-31.

Robichaud, D., Giroux, H. and Taylor, J.R. (2004). 'The Metaconversation: The Recursive Property of Language as a Key to Organizing' . Academy of Management Review, 29, 617634.

Schatzki, T.R., Knorr Cetina, K. and von Savigny, E. (2001) (eds.). The Practice Turn in Contemporary Theory. London: Routledge.

Schreyögg, G., and Sydow, J. (2010): 'Organizing for Fluidity? Dilemmas of New Organizational Forms’. Organization Science, 21, 1251-1262

Schoeneborn, D. (2011). 'Organization as communication: A Luhmannian perspective'. Management Communication Quarterly, 25, 663-689.

Schoeneborn, D. and Scherer, A. G. (2012). ,Clandestine organizations, al Qaeda, and the paradox of (in)visibility: A response to Stohl and Stohl'. Organization Studies, 33, 963971

Schultz, M. and Hernes, T. (2013). 'A Temporal Perspective on Organizational Identity'. Organization Science, 24, 1-21.

Seidl, D. (2005). Organisational identity and self-transformation: An autopoietic perspective. Burlington: Ashgate.

Seidl, D. (2007). 'General strategy concepts and the ecology of strategy discourses: a systemic-discursive perspective'. Organization Studies, 28, 197-218. 
Seidl, D. and Becker, K. H. (Eds.). (2005). Niklas Luhmann and organization studies. Copenhagen: Copenhagen Business School Press.

Seidl, D. and Becker, K. H. (2006). Organizations as distinction generating and processing systems: Niklas Luhmann’s contribution to organization studies. Organization, 13, 9-35.

Scott, C. (2013). Anonymous agencies, backstreet businesses, and covert collectives: Rethinking organizations in the 21st century. Stanford, CA: Stanford Business Books.

Stohl, C. and Stohl, M. (2011). 'Secret agencies: The communicative constitution of a clandestine organization’. Organization Studies, 32, 1197-1215.

Taylor, J. R. and Cooren, F. (1997). 'What makes communication 'organizational'? How the many voices of a collectivity become the one voice of an organization'. Journal of Pragmatics, 27, 409-438.

Taylor, J. R. and van Every, E. (2000). The emergent organization: Communication as its site and surface. Mahwah, NJ: Erlbaum.

Van de Ven, A.H. and Poole, M.S. (1995). 'Explaining development and change in organizations’. Academy of Management Review, 20, 510-540.

Wiesenfeld, B.M., Raghuram, S. and Garud, R. (1998). 'Communication Patterns as Determinants of Organizational Identification in a Virtual Organization'. Journal of Computer-Mediated Communication, 3, 0-0.

Ybema, S., Keenoy, T., Oswick, C., Beverungen, A., Ellis, N., \& Sabelis, I. (2009). Articulating identities. Human Relations, 62, 299-322.

Yin, R. K. (2009). Case Study Research (4th ed.). Thousand Oaks, CA: Sage. 